African Crop Science Journal by African Crop Science Society is licensed under a Creative Commons Attribution 3.0 Uganda License. Based on a work at www.ajol.info/ and www.bioline.org.br/cs DOI: https://dx.doi.org/10.4314/acsj.v27i2.7

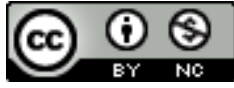

\title{
WHITEFLY RESISTANCE IN AFRICAN CASSAVA GENOTYPES
}

\author{
C. GWANDU ${ }^{1,2}$, M. OCHWO-SSEMAKULA ${ }^{2}$ and P. SSERUWAGI ${ }^{1}$ \\ ${ }^{1}$ Tanzania Agricultural Research Institute - Mikocheni, P. O. Box 6226, Dar es Salaam, Tanzania \\ ${ }^{2}$ College of Agricultural and Environmental Sciences, School of Agricultural Sciences, \\ Makerere University, P. O. Box 7062, Kampala, Uganda \\ Corresponding author: cathygwandu@yahoo.com
}

(Received 29 November 2018; accepted 16 May 2019)

\begin{abstract}
Whitefly (Bemisia tabaci), a major pest and vector of viruses in cassava, is the greatest current threat to cassava production in sub-Saharan Africa (SSA). Research efforts have focused on management of the two viral diseases: cassava mosaic disease (CMD) and cassava brown streak disease (CBSD), and have ignored the whitefly vector that is driving the spread of the viruses, causing CMD and CBSD in SSA. The objective of this study was to evaluate cassava genotypes for resistance to $B$. tabaci based on field infestation and damage in Uganda. The study was carried out in four sites with diverse agroecologies including: Namulonge, Kasese, Ngetta and Serere during 2015 and 2016. Whitefly nymph abundance and feeding damage were assessed on each test genotype from 3 to 6 months after planting (MAP). In 2015, the highest broad sense heritability estimates were 39\% (4 MAP) and 53\% (5 MAP) for whitefly nymph abundance and feeding damage, respectively. In 2016, broad sense heritability estimates were 23\% ( 3 MAP) and 41\% (4 MAP) for whitefly nymph abundance and feeding damage, respectively.Analysis of variance of whitefly nymph abundance showed a significant $(\mathrm{P}<$ $0.05)$ location $\times$ genotype $\times$ season interactions at $3,4,5$ and 6 MAP. There were also significant $(\mathrm{P}<$ 0.05 ) location $\times$ genotype $\times$ season interactions at 3 and 4 MAP for whitefly feeding damage. Ten genotypes showed good levels of resistance to whitefly infestation and feeding damage including: UG120202, UG120174, NASE13, UG120160, UG120286, UG120293, UG130075, CSI-142, CS1-144 and UG130085. These genotypes may serve as parental materials for breeding programmes for whitefly and viral disease control.
\end{abstract}

Key Words: Bemisia tabaci, cassava brown streak disease, cassava mosaic disease

\section{RÉSUMÉ}

La mouche blanche (Bemisia tabaci), le ravageur et vecteur principal de virus du manioc, constitue actuellement la plus grande menace pour la production de manioc en Afrique Subsaharienne (AS). Les recherches ont porté sur la gestion des deux maladies virales: la maladie de la mosaïque du manioc $(\mathrm{MMM})$ et la maladie de la striure brune du manioc (MSBM), et ont ignoré le vecteur de la mouche blanche qui est à l'origine de la propagation des virus, causant le MMMet le MSBM en Afrique 
subsaharienne. L'objectif de cette étude était d'évaluer la résistance de B. tabaci aux génotypes du manioc sur la base d'une infestation et de dégâts sur le champs en Ouganda. L'étude a été menée en 2015 et 2016 sur quatre sites présentant diverses agro-écologies, notamment Namulonge, Kasese, Ngetta et Serere. L'abondance des nymphes blanches et les dommages alimentaires ont été évalués sur chaque génotype testé 3 à 6 mois après la plantation (MAP). En 2015, les estimations les plus élevées de l'héritabilité au sens large étaient de 39\% (4 MAP) et 53\% (5 MAP) pour l'abondance des nymphes de la mouche blanche et les dommages causés par l'alimentation, respectivement. En 2016, les estimations de l'héritabilité au sens large étaient respectivement de 23\% (3 MAP) et 41\% (4 MAP) d'abondance des nymphes de la mouche blanche et des dommages causés par l'alimentation. L'analyse de la variance de l'abondance des nymphes de la mouche blanche a révélé une interaction significative $(\mathrm{p}<0,05)$ de lieu $\times$ génotype $\times$ interactions saisonnières à $3,4,5$ et 6 MAP. Il y avait aussi des interactions significatives $(\mathrm{P}<0,05)$ de lieu $\times$ génotype $\times$ interactions saisonnières aux niveaux de 3 et 4 MAP pour les dommages causés par l'alimentation des mouches blanches. Dix génotypes ont montré de bons niveaux de résistance à l'infestation par mouches blanches et aux dommages causés par l'alimentation, notamment: UG120202, UG120174, NASE13, UG120160, UG120286, UG120293, UG130075, CSI-142, CS1-144 et UG130085. Ces génotypes peuvent servir de matériel parental pour les programmes de sélection visant à lutter contre mouches blanches et les maladies virales.

Mots Clés: Bemisia tabaci, maladie de la striure brune du manioc, maladie de la mosaïque du manioc

\section{INTRODUCTION}

Whitefly, Bemisia tabaci (Gennadius) (Hemiptera: Aleyrodidae), is one of the world's most serious plant pests, and is a major vector of viral diseases in cassava (Legg, 2010). It is native to tropical and subtropical regions, but has spread rapidly around the world (Caro and Dumo, 2012). Bemisia tabaci is a polyphagous whitefly, colonising over 500 plant species from 74 families (Bellows et al., 1994). However, the monophagous B. tabaci populations have also been reported on Jatropha gossypifolia and Croton labatus (Jatropha races) and cassava B. tabaci, colonising cassava and wild eggplant in Africa (Lisha et al.,2003); and five other non-cassava plant species: Manihot glaziovii, Jatropha gossypifolia, Euphorbia heterophylla, Aspilia Africana and Abelmoschu sesculentus in Uganda (Sseruwagi et al., 2006).

Whitefly populations vary depending on the stage of plant growth of cassava (Fishpool et al., 1995; Sseruwagi et al.,2003). Adults invade slowly and establish within a sufficiently grown crop; and a small population appears after 3 weeks of the initial colonisation.
This is followed by rapid build up at 3 to 4 months after planting (Sseruwagi et al., 2004; Macfadyen et al., 2018). Rapid whitefly population growth occurs during this period, due to appropriate foliage support. A steady population growth follows for a short period, followed by a rapid decline to low residual level maintained throughout the rest of the crop's growth period (Fishpool et al., 1995).

Bemisia tabaci population dynamics and activity depend on nutritional quality of the host-plant, changes in the climatic factors (temperature, rain, wind and relative humidity), and natural enemy populations (Maria et al., 2003). Food resources are devoted to aerial growth during the early growth period (1 to 3 months), and decline after 4 to 5 months when the process of root tuberisation begins. A greater whitefly population during the first 3 months is usually observed, than when the plants are more mature (Marmey et al., 1994). Boost in whitefly population is favoured by high temperatures and radiation, and low rainfall and relative humidity (Fargette et al., 1985). The adults disperse mainly by the aid of wind, moving short and long distances (Blackmer et al., 1995), and also by the aid of 
humans who move immature and adult stages on planting material (Byrne and Bellows, 1991). Cropping practices such as planting date (Legg et al., 2011), crop disposition (Chikoti et al., 2013) and intercropping (Fargette et al.,1994) further influence whitefly population dynamics, and hence aid the spread of the whitefly-transmitted viruses.

In the initial stage of a whitefly infestation, the adults choose a host plant for feeding and/ or oviposition. Selection of the host plant may depend on several factors, such as leaf colour and colour of apical leaves (Baran et al., 1983), shape of central leaflet (Oriani et al., 2011), orientation of petiole, and hairy and/or smooth leaf (Nombela et al., 2000). For example, in cotton, whiteflies prefer light green leaves (Stansly, 1986). This color is believed to be the most important factor for whitefly host recognition (Berlinger, 1986).

A less open plant canopy is also preferred by whiteflies (Chen et al., 2004). Several studies have evaluated the preference of $B$. tabaci among cultivars of cotton, tomato and cassava, and found that whiteflies show preference for cultivars with moderately hairy leaves (Mohd Rasdi et al., 2009; Legg, 2010; Oriani et al., 2010).

Characters that affect whitefly feeding also affect oviposition. It was suggested that whiteflies choose the most suitable host for oviposition, not only because they can feed on it, but also because the offspring should be able to survive on it (Sharma et al., 2015). Therefore, growing cassava genotypes with genetic resistance (antixenosis) could be an effective, economic and ecofriendly method for controlling whitefly.

The direct feeding damage by whiteflies on cassava appears as chlorotic mottling and twisting or curling, particularly on upper leaves (Bellotti and Arias, 2001). If large populations develop early in the life of the crop, plant vigour and tuber sizes are reduced, and general plant stunting occurs. Another effect of the large whitefly populations is the production of honey dew, which falls onto the lower leaves. This is subsequently colonised by black sooty mould (Srinivasan et al., 2012), which reduces the ability of the leaves to photosynthesize and contribute to yield losses by over 50\% (Maruthi et al., 2017). The occurrence of black sooty mould on the upper surface of the lower leaves of cassava plants is now commonplace in countries like Uganda, and this recent phenomenon is referred to by farmers as "black mosaic". This name suggests that farmers are aware of the reduced yields that result, because "mosaic" is a term closely associated with the cassava mosaic disease (CMD) pandemic that has devastated cassava production in the country since the late 1980s, causing famine and suffering to the people whose livelihood depend on the crop (Thresh et al., 1994).

The greatest economic threat is from whitefly acting as a vector of: cassava mosaic begomoviruses (CMBs) and cassava brown streak viruses (CBSVs), which cause cassava mosaic disease (CMD) and cassava brown streak disease (CBSD), respectively. These diseases severely reduce cassava productivity in sub-Saharan Africa, causing more than US\$1 billion annually (Mbanzibwa et al., 2011; Legg et al., 2013). In the late 1990s, CMD was rapidly spread by the whitefly vector through southern Uganda and into neighbouring countries in East Africa (Legg et al., 2011). By the mid-2000s, 11 countries across East and Central Africa were affected by a severe CMD pandemic. Average yield losses of nearly $50 \%$ were reported due to CMD, causing food shortages and localised famine in the region.

Various control options were employed to manage the disease, although more emphasis was put on development of virus-resistant cassava varieties (Legg, 2010). Both conventional and transgenic breeding efforts were applied to identify sources of resistance and to incorporate these into farmer-preferred cassava varieties (Legg and Thresh, 2003). The International Institute of Tropical Agriculture (IITA) was the main source of 
germplasm for resistant breeding materials, as well as diverse collections of West African landraces (Legg, 2010).

Areas affected by the severe CMD epidemic in northern and central Uganda and at the 'fronts', were characterised by high whitefly abundance than in unaffected areas (Gibson, 1996; Legg et al., 2002). Since 2004, CMD and CBSD have spread over much of the Great Lakes Region of East and Central Africa (Alicai et al., 1994). The key factor believed to drive the spread of these viruses was the dramatic increase in abundance of their whitefly vector (Legg et al., 2013). Several resistant cassava varieties introduced to combat CMD and CBSD were later found to be highly suitable for $B$. tabaci and, thus exhibited limited whitefly resistance (Legg et al., 2014). This undesirable trait adversely affected the effectiveness of CMD and CBSD control strategies, because adult $B$. tabaci are highly mobile. However, little attention was given to B. tabaci until 2012, when possible resistance sources to whitefly were found in several Ugandan cassava landraces and a South American genotype (Omongo et al., 2012).

Recently, efforts in whitefly research have focused on understanding systematics, species diversity and ecology. Improved cassava genotypes have co-evolved with the virus and whitefly (Legg, 2010) and so an investigation into whitefly resistance is important to identify potentially useful genotypes for further resistance breeding and ultimately for development of effective management strategies for the increased whitefly populations now present in cassava production areas. In addition, whitefly resistance offers a low-cost, sustainable solution with the best chances of widespread adoption by subsistence farmers (Bellotti and Arias, 2001). The objective of this study was to determine sources of resistance of available cassava genotypes under high whitefly pressure in Uganda.

\section{MATERIALS AND METHODS}

Study sites and genetic materials. Field experiments were conducted in four diverse environments in Uganda, namely: Namulonge, Kasese, Ngetta and Serere (Table 1). The study was conducted for four months per cropping season from September to December 2015 (Season 1) and August to November 2016 (Season 2). Fifty diverse cassava genotypes that are part of a breeding population established in the Cassava Base genomic selection project (www.cassavabase.org) were used in the study (Table 2). The genotypes were selected based on parental diversity and agronomic performance.

Experimental design. The experiments were established in an augmented design, with the following five check clones: NASE 1 and TME 204 (highly susceptible and highly resistant to CMD and CBSD, respectively), TME14 and NASE 14 (highly susceptible and highly resistant to CMD and CBSD, respectively), and NASE 3 (resistant to CMD and susceptible to CBSD). At each location, the cassava genotypes were established in single unreplicate row plots of 10 plants, at a spacing of $1 \mathrm{~m} \mathrm{x} 1 \mathrm{~m}$ according to Kawuki et al. (2011).

Phenotypic data collection. Whitefly infestation and damage levels were recorded on the test genotypes, for four months at 3 , 4, 5 and 6 months after planting (MAP), the period of rapid whitefly build-up on cassava (Sseruwagi et al., 2003). This was done using three traits; namely whitefly nymph abundance/counts, feeding damage and plant morphological parameters. Whitefly feeding damage was assessed in the field on four plants per genotype, using a severity score scale of 1-5; in which1 represents no leaf damage; 2 represents $<25 \%$ of leaves damaged and with mild chlorosis on few apical leaves; 
TABLE 1. Agro-climatic description of the locations where test cassava genotypes were evaluated for whitefly cassava resistance in Uganda

\begin{tabular}{|c|c|c|c|c|}
\hline \multirow[t]{2}{*}{ Characteristics } & \multicolumn{4}{|c|}{ Site } \\
\hline & Namulonge & Serere & Ngetta & Kasese \\
\hline Whitefly abundance & High & Low & Low & High \\
\hline Temperature (min/max) & $16-28^{\circ} \mathrm{C}$ & $19-31^{\circ} \mathrm{C}$ & $19-29^{\circ} \mathrm{C}$ & $18-31{ }^{\circ} \mathrm{C}$ \\
\hline Rainfall & $\begin{array}{l}\text { Bimodal rainfall } 1^{\text {st }} \text { September } \\
\text { to November and } 2^{\text {nd }} \text { March } \\
\text { up to May of each year }\end{array}$ & $\begin{array}{l}\text { Bimodal rainfall } 1^{\text {st }} \text { September } \\
\text { to December/January and } \\
2^{\text {nd }} \text { February up to May/June } \\
\text { of each year }\end{array}$ & $\begin{array}{l}\text { Uni-modal rainfall } 1^{\text {st }} \text { October/ } \\
\text { November until April/May } \\
\text { of each year }\end{array}$ & $\begin{array}{l}\text { Uni-modal rainfall } 1^{\text {st }} \text { March } \\
\text { to May and } 2^{\text {nd }} \text { August up to } \\
\text { November of each year }\end{array}$ \\
\hline Mean rainfall (mm) & 1270 & 1419 & 1483 & 1200 \\
\hline Latitude & 0.5297 & 1.5176 & 53.6947 & 0.1833 \\
\hline Longitude & 0.1833 & 33.4579 & 22.9297 & 30.0833 \\
\hline Altitude (m.a.s.l) & 1150 & 1080 & 1300 & 960 \\
\hline Vegetation & $\begin{array}{l}\text { Transition forest with sandy } \\
\text { clay loam }\end{array}$ & Moist savannah & Moist savannah & Moist savannah \\
\hline
\end{tabular}


TABLE 2. Selected cassava genotypes for investigation for whitefly resistance in Uganda

\begin{tabular}{|c|c|c|c|c|}
\hline SN & Genotype & Female & Male & Pedigree/source \\
\hline 1 & UG120174 & MM96/0686 & MM96/0686 & Full sib of IITA clone $x$ IITA clone \\
\hline 2 & UG120191 & Introduction Tanzania & & $\begin{array}{l}\text { Selection from Tanzania Seed } \\
\text { Introduction-2005 }\end{array}$ \\
\hline 3 & UG130004 & Unknown & & Unknown \\
\hline 4 & UG120160 & CR21-6 & & Half sib of CIAT CR-Line \\
\hline 5 & UG130008 & $\mathrm{TZ} 140$ & & Half sib of Tanzania material \\
\hline 6 & UG130018 & Unknown & & Unknown \\
\hline 7 & UG120024 & MM96/4271 & Namikonga & $\begin{array}{l}\text { Full sib of IITA clone x Tanzania } \\
\text { clone-Namikonga }\end{array}$ \\
\hline 8 & UG130085 & NASE 13 & & Half sib of IITA Clone \\
\hline 9 & UG120251 & TMS 60142 & NASE 13 & Full sib of IITA clone $x$ IITA clone \\
\hline 10 & UG120170 & CR24-8 & & Half sib of CIAT CR-Line \\
\hline 11 & UG120227 & Njule red & & Half sib of Ugandan local \\
\hline 12 & UG120124 & MM96/4271 & MH04/2767 & Full sib of IITA clone $x$ IITA clone \\
\hline 13 & UG130068 & Unknown & & Unknown \\
\hline 14 & UG120127 & TZ130 & TZ130 & $\begin{array}{l}\text { Selfed progeny of Tanzanian } \\
\text { material }\end{array}$ \\
\hline 15 & UG130083 & Unknown & & unknown \\
\hline 16 & UG120198 & Introduction Tanzania & & $\begin{array}{l}\text { Selection from Tanzania Seed } \\
\text { introduction }-2005\end{array}$ \\
\hline 17 & UG120071 & TME 204 & MH95/0414 & Full sib of IITA clone $x$ IITA clone \\
\hline 18 & UG120133 & TMS30572 & & Half sib of IITA clone \\
\hline 19 & UG120063 & TME 204 & SE95/00036 & Full sib of IITA clone $x$ IITA clone \\
\hline 20 & UG120001 & TMS30572 & MH95/0414 & Full sib of IITA clone $x$ IITA clone \\
\hline 21 & UG130006 & TZ 140 & & Half Sib of Tanzania material \\
\hline 22 & UG130075 & Unknown & & unknown \\
\hline 23 & UG130078 & Unknown & & unknown \\
\hline 24 & UG120293 & TME 204 & & Half sib of IITA clone \\
\hline 25 & UG120252 & TMS 60142 & NASE 13 & Full sib of IITA clone $x$ IITA clone \\
\hline 26 & UG120286 & Kibao & CR36-2 & $\begin{array}{l}\text { Full Sib of CIAT CR-Line x } \\
\text { Ugandan local }\end{array}$ \\
\hline 27 & UG130038 & Unknown & & Unknown \\
\hline 28 & UG120295 & TME 204 & & Half sib of IITA clone \\
\hline 29 & UG120202 & SE95/00036 & MM96/4291 & Full sib of IITA clone $x$ IITA clone \\
\hline 30 & UG120109 & 40 & 40 & Selfed progeny of IITA clone \\
\hline 31 & UG120267 & TMS 60142 & TME 14 & Full sib of IITA clone $x$ IITA clone \\
\hline 32 & NAM 130 & Check & & \\
\hline 33 & UG120190 & Introduction Tanzania & & $\begin{array}{l}\text { Selection from Tanzania Seed } \\
\text { introduction - } 2005\end{array}$ \\
\hline 34 & CS1-114 & Check & & \\
\hline 35 & UG120193 & Introduction Tanzania & & $\begin{array}{l}\text { Selection from Tanzania Seed } \\
\text { introduction - } 2005\end{array}$ \\
\hline 36 & UG120283 & NASE 13 & TMS30572 & Full sib of IITA clone $x$ IITA clone \\
\hline 37 & UG120291 & TME 14 & & Half sib of IITA clone \\
\hline
\end{tabular}


TABLE 2. Contd.

\begin{tabular}{|c|c|c|c|c|}
\hline $\mathrm{SN}$ & Genotype & Female & Male & Pedigree/source \\
\hline 38 & UG120050 & TME 14 & Namikonga & $\begin{array}{l}\text { Full sib of IITA clone x Tanzania } \\
\text { clone-Namikonga }\end{array}$ \\
\hline 39 & UG120072 & TME 204 & MH95/0414 & Full sib of IITA clone $x$ IITA clone \\
\hline 40 & UG120161 & CR21-6 & & Half sib of CIAT CR-Line \\
\hline 41 & TP294 & Check & & \\
\hline 42 & CSI-75 & Check & & \\
\hline 43 & TME 14 & Check & & \\
\hline 44 & UG120220 & Unknown & & Unknown \\
\hline 45 & UG120189 & Introduction Tanzania & & $\begin{array}{l}\text { Selection from Tanzania seed } \\
\text { introduction }-2005\end{array}$ \\
\hline 46 & TME 204 & Check & & \\
\hline 47 & UG130029 & Unknown & & Unknown \\
\hline 48 & NASE 13 & Check & & \\
\hline 49 & UG120210 & MH97/2961 & Nyaraboke & $\begin{array}{l}\text { Full sib of IITA clone x Ugandan } \\
\text { local }\end{array}$ \\
\hline
\end{tabular}

3 represents $25-50 \%$ of leaves damaged with mild chlorosis, curled and twisted; 4 represents $50-75 \%$ of leaves damaged with moderate chlorosis and/or wilting; and 5 represents $>75 \%$ leaves damaged with defoliation (Sseruwagi et al., 2004).From each assessed plant, the $14^{\text {th }}$ leaf from the apex was detached from the plant as per Taylor et al. (2008) and the leaf gently dried with tissue to remove the moisture/water, and then placed in sealable plastic bags. Thereafter, the leaves were stored at $4{ }^{\circ} \mathrm{C}$ at the National Crops Resources Research Institute (NaCRRI), Namulonge. The nymphs were counted with the aid of a 10 magnifying hand lens. The following morphological parameters were assessed using a cassava descriptor protocol (Fakudo et al., 2010): (i) leaf colour, (ii) colour of apical leaves, (iii) shape of central leaflet, (iv) orientation of petiole and (v) hairy and/or smooth leaf.

Data analysis. Whitefly nymph abundance and feeding damage data were statistically analysed using $\mathrm{R}$ software ( $\mathrm{R}$ Core Team, 2013). Nymph count data were logarithmically transformed to normalise it. Analysis of variance (ANOVA) was conducted to determine significant differences among treatments. The ANOVA was conducted using a mixed linear model (MLM) with genotypes as fixed effects. Mean squares generated from ANOVA were used to test the significance of the different sources of variation and to calculate variance components. In addition, variance components extracted were used to estimate broad-sense heritabilities for the assessed traits determined by estimating the amount of genetic variance among the genotypes as a proportion of the total phenotypic variance.

The MLM used to extract the variances was as follows:

$\mathrm{Y}_{\mathrm{ijk}}=\mu+\mathrm{G}_{\mathrm{i}}+\mathrm{L}_{\mathrm{j}}+\mathrm{GL}_{\mathrm{ij}}+\mathrm{S}_{\mathrm{k}}+\mathrm{GS}_{\mathrm{ik}}+\mathrm{GSL}_{\mathrm{ijk}+} \varepsilon_{\mathrm{ijk}}$

Where:

Yijk is the observed phenotype for the $\mathrm{k}^{\text {th }}$ season in the $j^{\text {th }}$ location of the $i^{\text {th }}$ genotype evaluated in the experiment; $\mu$ is grand mean; $\mathrm{L}_{\mathrm{j}}$ is effect of location; $\mathrm{GL}_{\mathrm{ij}}$ is effect of interaction between genotype and location; $\mathrm{GS}_{\mathrm{ik}}$ is effect of interaction between genotype 
and season; $\mathrm{GSL}_{\mathrm{ijk}}$ is effect of interaction between genotype, season and location, and $\varepsilon_{\mathrm{ijk}}$ is residual.

The estimation of broad-sense heritability $\left(\mathrm{H}^{2}\right)$ was as follows:

$\mathrm{H}^{2}=\left(\mathrm{G}_{\mathrm{i}}\right) /\left[\left(\mathrm{G}_{\mathrm{i}}\right)+\left(\mathrm{GL}_{\mathrm{ij}} / \mathrm{n}_{\mathrm{l}}\right)+\left(\mathrm{GS}_{\mathrm{ik} / \mathrm{ns}}\right)+\left(\mathrm{GSL}_{\mathrm{ij} / \mathrm{j}}\right.\right.$ $\left.\left.{ }_{n} *^{*} n\right)+\varepsilon_{i j k} / n_{1} \times n_{s} \times n_{b}\right]$

Where:

$\mathrm{nl}$ is number of locations, $\mathrm{n}_{\mathrm{s}}$ is number of seasons and $n_{b}$ is number of blocks.

Pearson's correlation coefficients $\left(r_{x y}\right)$ were computed to determine the degree of association between whitefly feeding damage and nymph counts, using the following formula:

$r_{x y}=\sum_{i=n}^{n} \frac{\left(x_{i}-\bar{x}\right)\left(y_{i}-\bar{y}\right)}{(n-1) s_{x} s_{y}}$

Where:

$x_{i}$ and $y_{i}$ are the genotype means of the two variables being analysed and $n$ is the total number of observations of each variable.

\section{RESULTS}

Whitefly nymph abundance and feeding damage. In season 1 (2015), the highest variability for nymph abundance $(>0<2000)$ was recorded at 3 MAP in Kasese and Serere (Fig. 1A). Nymph populations were normally distributed at Namulonge (NaCRRI), Ngetta and Serere (Fig. 1A). The highest variability for whitefly damage (severity scores $>2<4$ ) was recorded at 5 MAP in Namulonge and Serere (Fig. 1B). Whitefly feeding damage data were only normally distributed at Kasese (Fig. 1B). In season 2 (2016), the highest variability for nymph abundance $(>0<1500)$ occurred at 3MAP in Ngetta only (Fig. 1C). Whitefly nymph populations were not normally distributed across all the locations. The highest variability for whitefly damage (severity scores $>2<5$ ) occurred at 5 MAP across all locations (Kasese, Namulonge, Serere and Ngetta). However, whitefly feeding damage data were normally distributed only at Namulonge (Fig. 1D).

Broad-sense heritability. In 2015, the highest broad sense heritability estimates were 39\% (4 MAP) and 53\% (5 MAP) for whitefly nymph abundance and feeding damage, respectively. In 2016, broad sense heritability estimates reduced to $23 \%$ (3 MAP) and $41 \%$ (4 MAP) for whitefly nymph abundance and feeding damage, respectively.

Whitefly resistance traits. There were significant differences in whitefly nymph abundance between genotypes at 3,4 and 6 MAP $(\mathrm{P}<0.001)$ and at 5 MAP $(\mathrm{P}<0.01)$ (Table $3)$. Nymph abundance was highly significantly different between locations at 4 and 5 MAP $(\mathrm{P}<0.001)$, and at $3(\mathrm{P}<0.05)$ and 6 MAP $(\mathrm{P}<0.01)$. Furthermore, there were significant genotypex season interactions for nymph abundance at $3,4,5(\mathrm{P}<0.05)$ and $6(\mathrm{P}<0.001)$ MAP. Location $\mathrm{x}$ genotype interaction for nymph abundance was not significant. However, the location $\mathrm{x}$ genotype $\mathrm{x}$ season interactions were significantly different at 4 , 5 and 6 MAP $(\mathrm{P}<0.001)$ and at 3 MAP $(\mathrm{P}<0.05)$.

There were similarly significant differences in whitefly feeding damage among genotypes at 3 and 5 MAP $(\mathrm{P}<0.001$; Table 3$)$. There were highly significant differences in whitefly feeding damage among genotypes $(\mathrm{P}<0.01)$ at 4 and 6 MAP, and among locations $(\mathrm{P}<0.001)$ at 3, 4, 5 and 6 MAP. Whitefly feeding damage was highly significant between seasons $(\mathrm{P}<$ 0.001 ) at $6 \mathrm{MAP}$, with similar results at 4 and 5 MAP $(\mathrm{P}<0.01)$. In addition, there were significant location $\times$ genotype interactions for whitefly feeding damage eat $3 \mathrm{MAP}(\mathrm{P}<0.05)$ and 5 MAP $(\mathrm{P}<0.01)$. At 3 and 4 MAP, significant genotype $\times$ season $(\mathrm{P}<0.01)$ and 
A

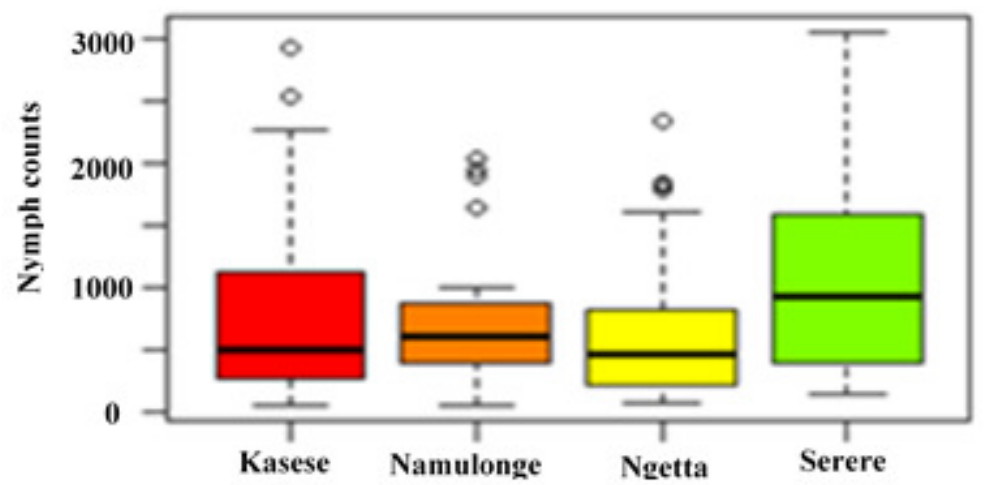

C

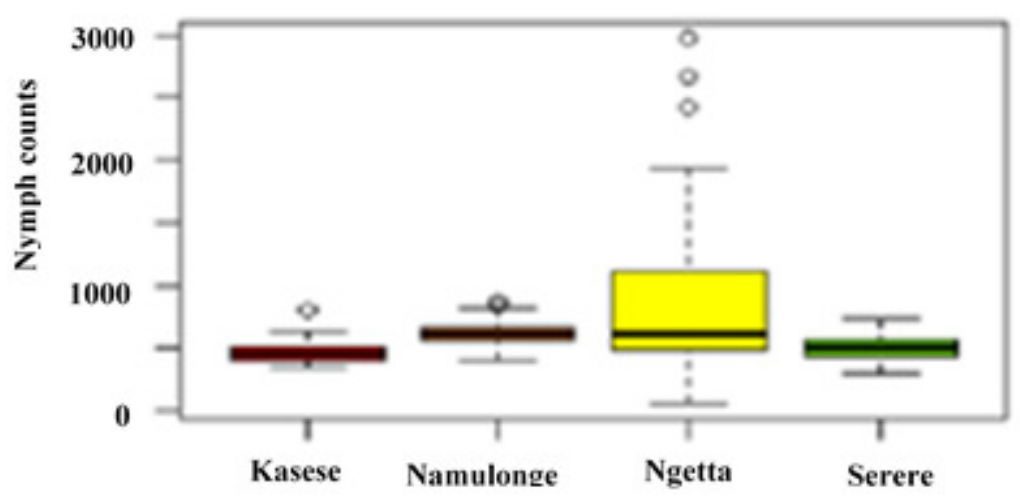

3 MAP
B

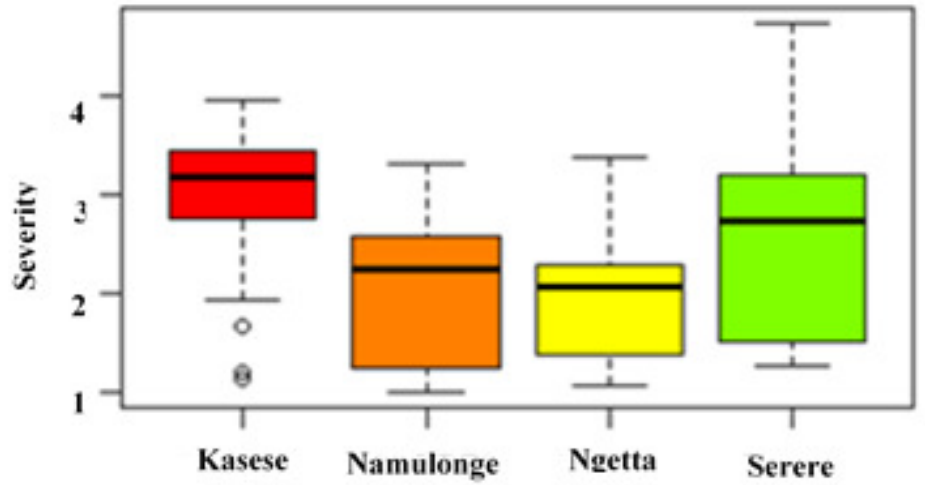

D

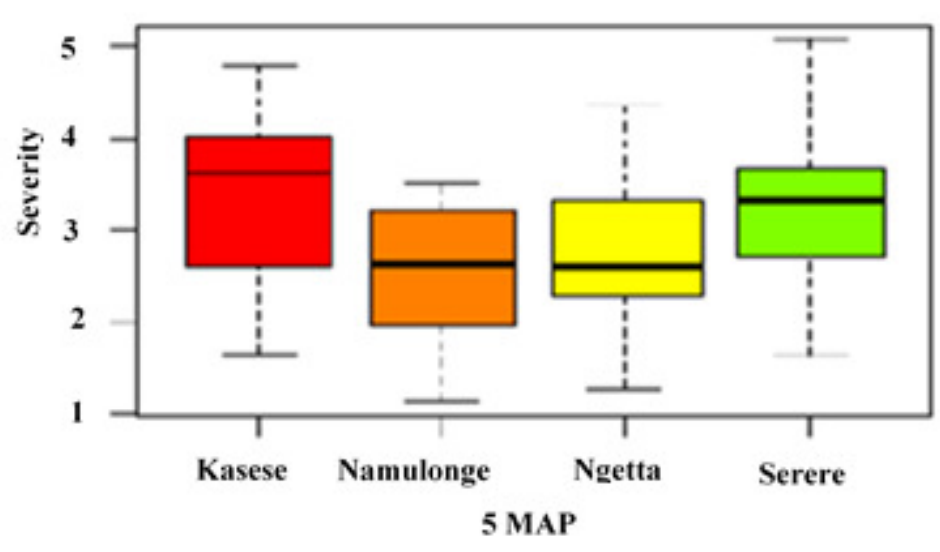

Figure 1. Stage of crop growth with highest variability and distribution of whitefly nymphs and damage across locations in 2015 (A \& B) and 2016 (C \& D) in Uganda. 
TABLE 3. Mean squares associated with whitefly resistance evaluations at different growth stages, across locations and seasons in Uganda

\begin{tabular}{|c|c|c|c|c|c|c|c|c|c|}
\hline \multirow[t]{2}{*}{ Source of variance } & \multirow[t]{2}{*}{ d.f } & \multicolumn{4}{|c|}{ Nymph counts (logarithmic transformed) } & \multicolumn{4}{|c|}{ Whitefly damage } \\
\hline & & 3 MAP & 4 MAP & $5 \mathrm{MAP}$ & $6 \mathrm{MAP}$ & 3 MAP & 4 MAP & 5 MAP & $6 \mathrm{MAP}$ \\
\hline Genotype & 49 & $0.179 * * *$ & $0.198 * * *$ & $0.166^{* *}$ & $0.234 * * *$ & $0.699 * * *$ & $0.821 * *$ & $1.115 * * *$ & $1.003 * *$ \\
\hline Location & 3 & $0.270^{*}$ & $1.468 * * *$ & $5.119 * * *$ & $0.592 * *$ & $10.832 * * *$ & $11.393 * * *$ & $22.976 * * *$ & $27.484 * * *$ \\
\hline Blocks & 4 & 0.322 & 0.296 & 0.219 & 0.446 & 0.668 & 1.129 & 0.751 & 0.427 \\
\hline Season & 1 & 0.030 & $0.612 * *$ & $0.976 * * *$ & $1.794 * *$ & 1.113 & $3.0624 * *$ & $39.982 * *$ & $64.853 * * *$ \\
\hline Checks & 5 & 0.462 & 0.439 & 0.137 & 0.132 & 1.235 & 1.022 & 2.135 & 1.297 \\
\hline Location: Genotype & 159 & 0.035 & 0.035 & 0.070 & 0.083 & $0.389 *$ & 0.486 & $0.746 * *$ & 0.78 \\
\hline Genotype: Season & 54 & $0.089^{*}$ & $0.066^{*}$ & $0.130 * *$ & $0.181 * * *$ & $0.392 * *$ & $0.334 * *$ & 0.425 & 0.506 \\
\hline Location: Genotype: Season & 122 & $0.103^{*}$ & $0.159 * * *$ & $2.752 * * *$ & $0.282 * * *$ & $0.376^{*}$ & $0.531 *$ & 0.474 & 0.816 \\
\hline Residual & 124 & 0.074 & 0.079 & 0.066 & 0.088 & 0.289 & 0.378 & 0.446 & 0.522 \\
\hline s.e.d & & 0.019 & 0.020 & 0.018 & 0.021 & 0.038 & 0.043 & 0.047 & 0.022 \\
\hline
\end{tabular}

D.f $=$ degrees of freedom; 3 MAP, 4 MAP, 5MAP and 6MAP are three, four, five and six months after planting, respectively. *, ** and $* * *$ represents significance at $\mathrm{P}<0.05,0.01$, and 0.001 , respectively 
location $\times$ genotype $\times$ season $(\mathrm{P}<0.05)$ interactions were observed for whitefly feeding damage.

Correlations among traits. In 2015, there were high correlations between whitefly nymph abundance and feeding damage $3(\mathrm{r}=$ $0.789)$ and $4(\mathrm{r}=0.656)$ MAP, respectively. However, the correlations between nymph abundance and feeding damage at $5(\mathrm{r}=0.469)$ and $6(r=0.221)$ MAP were weak. Similarly, in 2016 high correlation coefficients $(r=$ 0.656 and $r=0.639$ ) were observed between whitefly nymph abundance and feeding damage at 3 and 4 MAP, respectively. However, the correlation coefficients were similarly weak at $5(\mathrm{r}=0.232)$ and $6(\mathrm{r}=0.295)$ MAP, respectively.

Categorising genotype for whitefly resistance. Whitefly nymph abundance and feeding damage were used to categorise cassava genotype responses to whitefly resistance (Table 4). The ten most whitefly resistant genotypes were: UG120202, UG120174, NASE13, UG120160, UG120286, UG120293, UG130075, CSI-142, CS1-144 and UG130085, with mean whitefly nymph abundance of 2.689-3.624 and feeding damage of 2.017-2.989. Genotypes UG120189, UG130066, UG120133, UG120170, UG120198, UG130038, UG130078, UG120161, UG120220 and UG120251 were the most susceptible, based on mean scores of 2.25-2.89 for whitefly nymph abundance and 3.759-4.624 for whitefly feeding damage (Table 4).

Out of the ten whitefly resistant genotypes identified in this study, UG120202, UG120174, NASE13, UG120160, UG120286, UG120293 and CSI-142 recorded the least whitefly damage, with mean feeding damage scores of $>2.017<2.478$, with corresponding mean nymph abundance of $>1.296<1.780$. Genotypes UG130075, CS1-144 and UG130085 had mean nymph abundance of $>1.840<2.396$ and mean whitefly feeding damage of $>2.527<2.989$.

Of the most whitefly susceptible genotypes, UG130078, UG120161, UG120220 and UG120251 had mean nymph abundance of $>2.786<2.892$, and the highest mean whitefly feeding damage scores of $>4.033<4.624$. Similarly, genotypes

TABLE 4. Ten most whitefly (Bemisia tabaci) resistant cassava genotypes evaluated in Uganda

\begin{tabular}{|c|c|c|c|c|c|}
\hline \multicolumn{3}{|c|}{ Resistant } & \multicolumn{3}{|c|}{ Susceptible } \\
\hline Genotype & $\begin{array}{l}\text { Whitefly } \\
\text { damage }\end{array}$ & $\begin{array}{l}\text { Nymph } \\
\text { counts (log) }\end{array}$ & Genotype & $\begin{array}{l}\text { Whitefly } \\
\text { damage }\end{array}$ & $\begin{array}{c}\text { Nymph } \\
\text { counts (log) }\end{array}$ \\
\hline 1. UG120202 & 2.017 & 1.296 & UG120189 & 2.689 & 2.248 \\
\hline 2. UG120174 & 2.364 & 1.332 & UG130066 & 2.804 & 2.297 \\
\hline 3. NASE13 & 2.369 & 1.402 & UG120133 & 2.835 & 2.315 \\
\hline 4. UG120160 & 2.406 & 1.425 & UG120170 & 2.908 & 2.403 \\
\hline 5. UG120286 & 2.418 & 1.703 & UG120198 & 2.938 & 2.736 \\
\hline 6. UG120293 & 2.478 & 1.748 & UG130038 & 2.981 & 2.767 \\
\hline 7. CSI-142 & 2.478 & 1.780 & UG130078 & 3.033 & 2.786 \\
\hline 8. UG130075 & 2.527 & 1.840 & UG120161 & 3.134 & 2.791 \\
\hline 9. CS1-144 & 2.567 & 2.384 & UG120220 & 3.624 & 2.860 \\
\hline 10.UG130085 & 2.579 & 2.396 & UG120251 & 3.624 & 2.892 \\
\hline $\operatorname{LSD}(0.05)$ & 0.076 & 0.048 & $\operatorname{LSD}(0.05)$ & 0.047 & 0.051 \\
\hline
\end{tabular}


UG120189, UG130066, UG120133, UG120170, UG120198 and UG130038 had mean nymph abundance of $>2.248<2.767$ and relatively high mean whitefly feeding damage of $>3.759<3.981$.

\section{Morphological genotypes.}

characterisation of The morphological characterisation of cassava genotypes for whitefly preference and colonisation was based on leaf colour, colour of apical leaves, and shape of the central leaflet, orientation of petioles and hairiness and/or smoothness of leaves. Apical leaves of the whitefly resistant genotypes: UG120202, UG120174, NASE13, UG120160, UG120286, UG120293 and CSI142 were dark green, and UG130075, CS1144 and UG130085 had light green foliage. The central leaflets of UG120202, UG120174, NASE13, UG120286, UG120293 and CS1144 were elliptic-lanceolate shaped and straight; and linear for UG120160, CSI-142 and UG130075. The petioles for genotypes NASE13, UG120160, CSI-142, UG120202, UG120174, CS1-144 and UG130085 were inclined upwards; and reflexed downwards for UG120286 and UG120293. Genotypes UG120202, UG120174, NASE13, UG120286, UG120293 and CS1-144 had smooth leaves, while UG120160, CSI-142, UG130075 and UG130085 possessed hairy leaves.

\section{DISCUSSION}

At least 10 cassava genotypes showed good levels of resistance to whitefly infestation and damage, including: UG120202, UG120174, NASE13, UG120160, UG120286, UG120293, UG130075, CSI-142, CS1-144 and UG130085 (Table 4).

Variability in whitefly nymph abundance and feeding damage at different crop growth stages and across locations (Fig. 1) suggests that evaluation should be conducted across multiple environments. Low broad-sense heritability estimates were obtained at different crop growth stages and across different locations for whitefly nymph abundance and feeding damage. The low estimates for broadsense heritability may indicate that inheritance of whitefly resistance traits is complex.

The significant differences observed among genotypes in the current study, both within and across seasons (Fig. 1A), suggest high genetic variability among the tested cassava genotypes. It seems therefore, that the 10 genotypes identified in our study may serve as good candidate parental materials for breeding programmes aimed at developing whitefly and viral disease resistant cassava. However, research is still required to fully understand the mechanisms and genetic bases of the resistance in these genotypes, which will aid in the retrogression of the whitefly resistant genes into the available viral disease resistant cassava cultivars.

The significant location effects associated with whitefly resistance traits within and across seasons (Table 3 ) showed that the field conditions in these locations differed and strongly affected whitefly resistance assessments. This suggests that future evaluation of cassava genotypes for whitefly resistance should be conducted in areas with high whitefly abundance. Resources should not be wasted on screening for whitefly resistance in low whitefly abundance areas. Conversely, the significant difference observed for season $\times$ genotype interactions at different crop growth stages, implied that season influenced genotype performance in relation to whitefly nymph abundance and feeding damage. The results show that the field conditions in all the study locations and seasons significantly affected genotype performance with regards to whitefly nymph abundance and feeding damage. Whitefly gradually infest and colonise cassava crops starting at 2 until 5 months after planting (MAP); and often peak at 3 and 4 MAP (Sseruwagi et al., 2003). This was evident in the present study as supported by the significant positive correlations between whitefly nymph abundance/infestation and 
feeding damage at 3 and 4 MAP. The effect was more evident in the 2015 than 2016 at 4, 5 and 6 MAP cropping seasons; emphasizing the importance of seasonal effects on whitefly infestation and damage on cassava.

Morphological characterisation of cassava genotypes with respect to whitefly preference and colonisation confirmed the characteristic traits of resistant genotypes to include: leaf and apical leaves colour. These are the traits that defined genotypes UG120174, UG120191 and UG130004 that had the lowest nymph abundance and feeding damage. Our findings are consistent with those reported by Legg (2010).

Genotypes UG130075, CS1-144 and UG130085 that had light green foliage were better hosts to $B$. tabaci, than cultivars UG120202, UG120174, NASE13, UG120160, UG120286, UG120293 and CSI-142 with dark green foliage. Our results are consistent with those of Stansly (1995), who showed that $B$. tabaci adults preferentially fed and oviposited more on light green than on dark green leaf cultivars. Elsewhere, studies evaluating poinsettia cultivars in relation to $B$. tabaci preference and performance also showed that light green leaf cultivars were more susceptible than dark green leaf cultivars (Berlinger, 1986).

Dark green leaf cultivars have higher phenolic content and thickness of the leaves, which may be the resistance mechanism playing a major role in relation to $B$. tabaci performance and behaviour (Shibuya et al., 2010). Phenols are plant secondary metabolites involved in plant defense against insects such as B. tabaci (Mwila et al., 2017). The phenols are directly toxic to the insects and/or act as feeding deterrents (Chu et al., 2017). These effects were also reported by Mwila et al. (2017), who showed the phenolic compounds to constitute a diverse group of plant secondary metabolites involved in plant defense against insect pests. The phenolics containan a stringent (mouth puckering) and bitter taste that deters insect pests. These compounds bind to the insect midgut proteins and digestive enzymes and precipitate them through hydrogen or covalent bonds, thereby limiting their availability to the insect pests, ultimately reducing insect growth and development. Therefore, we recommend that cassava farmers should grow darker green leaf cultivars because they are inherently less preferred by B. tabaci compared to the lighter green leaf foliage. Leaf orientation also seemed to be important, as genotypes with leaflets reflexed upward about the midrib supported fewer whiteflies than those reflexed downwards. Similar results were reported by Butler et al. (1983) in cotton plants. Byrne and Bellows (1991) reported leaf hairs to interfere with whitefly landing and feeding on cassava and proposed it to be a likely trait of whitefly resistance.

\section{ACKNOWLEDGEMENT}

The study was supported by Ministry of Agricultural Food Security and Cooperatives of United Republic of Tanzania, with funding from Tanzania Agricultural Research InstituteMikocheni.

\section{REFERENCES}

Alicai, T., Omongo, C.A., Maruthi, M.N., Hillocks, R.J., Baguma, Y., Kawuki, R., Bua, A., W, Otim-Nape G and Colvin, J. 1994. Re-emergence of Cassava Brown Streak Disease in Uganda. Plant Disease 91: 24-9.

Baran, N., Neer, A. and Manor, H. 1983. "Onion skin" replication of integrated polyoma virus DNA and flanking sequences in polyoma-transformed rat cells: termination within a specific cellular DNA segment. Proceedings of the National Academy of Sciences of the United States of America 80:10-59.

Bellotti, A.C. and Arias, B. 2001. Host plant resistance to whiteflies with emphasis on cassava as a case study. Crop Protection 20:813-23. 
Bellows, T.S., Perring, T.M., Gill, R.J. and Headrick, D.H. 1994. Description of a Species of Bemisia (Homoptera/ : Aleyrodidae). Annals of the Entomological Society of America 87:195-206.

Berlinger, M.J. 1986. Host plant resistance to Bemisia tabaci. Agriculture, Ecosystems and Environment 17: 69-82.

Blackmer, J.L., Byrne, D.N. and T, Z. 1995, Behavioral. Morphological , and Physiological Traits Associated with Migratory Bemisia tabaci (Homoptera/ : Aleyrodidae).Journal of Insect Behavior 8:251-67.

Butler, G.D., Henneberry, T.J. and Clayton, T.E. 1983. Bemisia tabaci (Homoptera: Aleyrodidae): Development, Oviposition, and Longevity in Relation to Temperature1.Annals of the Entomological Society of America 76:310-3.

Byrne, D.N. and Bellows, T.S. 1991. Whitefly Biology. Annual Review of Entomology 36:431-57.

Chikoti, P.C., Ndunguru, J., Melis, R., Tairo, F., Shanahan, P. and Sseruwagi, P. 2013. Cassava mosaic disease and associated viruses in Zambia: occurrence and distribution. International Journal of Pest Management 59: 63-72.

Chu, B., Zhang, S., Wang, L., Zhu, X., Luo, J., Wang, C., Lü, L. and Cui, J. 2017. Genetic regulation of defence responses in cotton to insect herbivores. Asia-Pacific Entomology 20:341-51.

Fakudo, W.M.G, Guevara, C.L., Kawuki, R. and Ferguson, M.E. 2010. Selected morphological and agronomic descriptors for the characterization of cassava.www.iita.org.

Fargette, D., Fauquet, C. and Thouvenel, J. 1985. Field studies on the spread of African cassava mosaic.Annals of Applied Biology 106:285-94.

Fargette, D., Fauquet, C. and Thresh, J.M. 1994. Analysis and modelling of the temporal spread of African cassava mosaic virus and implications for disease control. African Crop Science Journal 2: 449-58
Fishpool, L.D.C., Fauquet, C., Fargette, D., Thouvenel, J.C., Burban, C. and Colvin, J. 1995. The phenology of Bemisia tabaci (Homoptera: Aleyrodidae) populations on cassava in southern Côte d'Ivoire.Bulletin of Entomological Research 85:197-207.

Gibson, R.W., Legg, J.P. and Otim-Nape, G.W. 1996. Unusually severe symptoms are a characteristic of the current epidemic of mosaic virus disease of cassava in Uganda.Annals of Applied Biology 128:479-90.

Kawuki, R., Pariyo, A., Nuwamanya, E., Ssemakula, G., Tumwesigye, S., Bua, A., Baguma, Y., Omongo, C., Alicai, T. and Orone, J. 2011. A breeding scheme for local adoption of cassava (Manihot esculenta Crantz).Journal of Plant Breeding and Crop Science 3:120-30.

Legg, J.P. 2010. Epidemiology of a WhiteflyTransmitted Cassava Mosaic Geminivirus Pandemic in Africa.Springer Science 1996:233-57.

Legg, J.P., Jeremiah, S.C., Obiero, H.M., Maruthi, M.N., Ndyetabula, I., OkaoOkuja, G., Bouwmeester, H., Bigirimana, S., Tata-Hangy, W., Gashaka, G., Mkamilo, G., Alicai, T. and Lava Kumar, P. 2011. Comparing the regional epidemiology of the cassava mosaic and cassava brown streak virus pandemics in Africa.Virus Research 159:161-70.

Legg, J.P., Sseruwagi, P., Boniface, S., OkaoOkuja, G., Shirima, R., Bigirimana, S., Gashaka, G., Herrmann, H.W., Jeremiah, S., Obiero, H., Ndyetabula, I., Tata-Hangy, W., Masembe, C. and Brown, J.K. 2014. Spatio-temporal patterns of genetic change amongst populations of cassava Bemisia tabaci whiteflies driving virus pandemics in East and Central Africa. Virus Research 186:61-75.

Legg, J.P. and Thresh, J.M. 2003. Cassava virus diseases in Africa.Plant virology in subSaharan Africa517-52.

Lisha, V.S., Antony, B. and Palaniswami, M.S. 2003. Bemisia tabaci (Homoptera/ : 
Aleyrodidae) Biotypes in India.Journal of Economic Entomology (96)2:322-7.

MacFadyen, S., Paull, C., Boykin, L.M., De Barro, P., Maruthi, M.N., Otim, M., Kalyebi, A., Vassão, D.G., Sseruwagi, P., Tay, W.T., Delatte, H., Seguni, Z., Colvin, J. and Omongo, C.A. 2018. Cassava whitefly, Bemisia tabaci (Gennadius) (Hemiptera: Aleyrodidae) in East African farming landscapes: A review of the factors determining abundance.Bulletin of Entomological Research 108:565-82.

Maria R.V. De O, Everton A, R.A. and L.O. 2003. Natural Enemies of Bemisia tabaci (Gennadius) B Biotype and Trialeurodes vaporariorum (Westwood) (Hemiptera/ : Aleyrodidae) in Brasília, Brazil. Neotropical Entomology 32:151-4.

Marmey, P., Beeching, J.R., Hamon, S. and Charrier, A. 1994. Evaluation of cassava (Manihot esculenta Crantz) germplasm collections using RAPD markers.Euphytica74:203-9.

Maruthi, M.N., Jeremiah, S.C., Mohammed, I.U. and Legg, J.P. 2017. The role of the whitefly, Bemisia tabaci (Gennadius), and farmer practices in the spread of cassava brown streak ipomoviruses. Journal of Phytopathology 165: 707-17.

Mbanzibwa, D.R., Tian, Y.P., Tugume, A.K., Patil, B.L., Yadav, J.S., Bagewadi, B., Abarshi, M.M., Alicai, T., Changadeya, W., Mkumbira, J., Muli, M.B., Mukasa, S.B., Tairo, F., Baguma, Y., Kyamanywa, S., Kullaya, A., Maruthi, M.N., Fauquet, C.M. andValkonen, J.P.T. 2011. Evolution of cassava brown streak disease-associated viruses.Journal of General Virology 92:974-87.

Mohd Rasdi, Z., Fauziah, I., Fairuz, K., Mohd Saiful Akbar, M.S., Md Jamaludin, B., Che Salmah, R. and Kamaruzaman, J. 2009. Population Ecology of Whitefly, Bemisia tabaci, (Homoptera: Aleyrodidae) on Brinjal. Journal of Agricultural Science 1:27-32.

Mwila, N., Rubaihayo, P.R., Kyamanywa, S., Odong, T.L., Nuwamanya, E., Mwala, M.,
Agbahoungba, S. and Badji, A. 2017. Biochemical factors associated with cassava resistance to whitefly infestation. African Crop Science 25:365-85.

Nombela, G., Beitia, F., Muñiz, M. and Dpdo, S. 2000. Variation in tomato host response to Bemisia tabaci (Hemipteral : Aleyrodidae) in relation to acyl sugar content and presence of the nematode and potato aphid resistance gene Mi.Bulletin of Entomological Research 90: 161-7.

Omongo, C., Kawuki, R., Bellotti, A.C., Alicai, T., Baguma, Y., Maruthi, M.N. and Colvin, J. 2012. African Cassava Whitefly, Bemisia tabaci, Resistance in African and South American Cassava Genotypes.Journal of Integrative Agriculture 11:327-36.

Oriani, M.A. de G., Vendramim, J.D. and Vasconcelos, C.J. 2011. No-choice ovipositional nonpreference of Bemisia tabaci (Gennadius) B biotype on tomato genotypes.Scientia Agricola 68:147-53.

R Core Team (2013). R: A language and environment for statistical computing.

Vienna, Austria.

Sharma, M., Budha, P.B. and Pradhan, S.B. 2015. Efficacy Test of Bio-pesticides against Tobacco Whitefly Bemisia tabaci (Gennadius, 1889) on Tomato Plants in Nepal.Journal of Institute of Science and Technology 20:11.

Shibuya, T., Hirai, N., Sakamoto, Y. and Endo, R. 2010. Preference of Sweetpotato Whitefly Adults to Cucumber Seedlings Grown under Two Different Light Sources.Horttechnology 20:5 873-876.

Srinivasan, R., Riley, D., Diffie, S., Sparks, A. and Adkins, S. 2012. Whitefly Population Dynamics and Evaluation of Whitefly-Transmitted Tomato Yellow Leaf Curl Virus (TYLCV)-Resistant Tomato Genotypes as Whitefly and TYLCV Reservoirs.Journal of Economic Entomology 105:1447-56.

Sseruwagi, P, G.W.Otim-Nape, D.S.O.O. and and Thresh, J.M. 2003. Influence of NPK fertilizer on population of the whitefly 
vector and incidence of cassava mosaic virus disease.African Crop Science Journal 11:0-5.

Sseruwagi, P., Maruthi, M.N., Colvin, J., Rey, M.E.C., Brown, J.K. and Legg, J.P. 2006 Colonization of non-cassava plant species by cassava whiteflies (Bemisia tabaci) in Uganda. The Netherlands Entomological Society 119:145-53.

Sseruwagi, P., Sserubombwe, W.S., Legg, J.P., Ndunguru, J. and Thresh, J.M. 2004. Methods of surveying the incidence and severity of cassava mosaic disease and whitefly vector populations on cassava in Africa. Crop Protection 100:129-42.

Stansly, T.-X.L. and P.A. 1986. Life history of Bemesia Argentifolii (Homoptera: Aleyrodidae) on Hibiscus Rosa-Sinensis (Malvaceae). Florida Entomology 437-45. Thresh, J.M., Fargette, D. and Otirn-Nape, G.W. 1994. Effects of African cassava mosaic geminivirus on the yield of cassava.Tropical Science 34:26-42. 